\title{
Bisphenol A modulates receptivity and secretory function of human decidual cells: an in vitro study
}

\author{
Chiara Mannelli ${ }^{1,2}$, Anna Z Szóstek ${ }^{1}$, Karolina Lukasik ${ }^{1}$, Claudiopietro Carotenuto $^{2}$, \\ Francesca letta ${ }^{2}$, Roberta Romagnoli ${ }^{2}$, Cristina Ferretti ${ }^{3}$, Luana Paulesu ${ }^{2}$, Slawomir Wołczynski $i^{1,4}$ \\ and Dariusz Jan Skarzynski ${ }^{1}$ \\ ${ }^{1}$ Institute of Animal Reproduction and Food Research, Polish Academy of Sciences, Tuwima Street 10, 10-748 \\ Olsztyn, Poland, ${ }^{2}$ Department of Life Sciences, University of Siena, Via A. Moro, 2, Siena 53100, Italy, ${ }^{3}$ Obstetrics and \\ Gynecology Division, Local Health Authority 7, Campostaggia Hospital, Siena, Italy and ${ }^{4}$ Department of \\ Reproduction and Gynecological Endocrinology, Medical University, Bialystok, Poland
}

Correspondence should be addressed to D J Skarzynski; Email: d.skarzynski@pan.olsztyn.pl

\begin{abstract}
The human endometrium is a fertility-determining tissue and a target of steroid hormones' action. Endocrine disruptors (EDs) can exert adverse effects on the physiological function of the decidua at the maternal-fetal interface. We examined the potential effects of an ED, bisphenol A (BPA), on endometrial maturation/decidualization, receptivity, and secretion of decidual factors (biomarkers). In vitro decidualized, endometrial stromal cells from six hysterectomy specimens were treated with $1 \mathrm{pM}-1 \mu \mathrm{M}$ of BPA, for $24 \mathrm{~h}$ and assessed for cell viability and proliferation. Three non-toxic concentrations of BPA ( $1 \mu \mathrm{M}, 1 \mathrm{nM}$, and $1 \mathrm{pM})$ were selected to study its influence on secretion of cell decidualization biomarkers (IGF-binding protein and decidual prolactin (dPRL)), macrophage migration inhibitory factor (MIF) secretion, and hormone receptors' expression (estrogen receptors (ER $\alpha$ and ERß); progesterone receptors (PRA and PRB); and human chorionic gonadotropin (hCG)/LH receptor (LH-R)). The results showed a decrease in cell viability $(P<0.001)$ in response to $B P A$ at the level of $1 \mathrm{mM}$. At the non-toxic concentrations used, BPA perturbed the expression of ER $\alpha$, ER $\beta$, PRA, PRB, and hCG/LH-R $(P<0.05)$. Furthermore, $1 \mu \mathrm{M}$ of BPA reduced the mRNA transcription of $d P R L(P<0.05)$. Secretion of MIF was stimulated by all BPA treatments, the lowest concentration $(1 \mathrm{pM})$ being the most effective $(P<0.001)$. The multi-targeted disruption of BPA on decidual cells, at concentrations commonly detected in the human population, raises great concern about the possible consequences of exposure to $B P A$ on the function of decidua and thus its potential deleterious effect on pregnancy.
\end{abstract}

Reproduction (2015) 150 115-125

\section{Introduction}

\section{Bisphenol $A$ effects and presence in the human body}

Bisphenol A (BPA) is one of the most common endocrine disruptors to which we are exposed throughout our life, from prenatal to adult age. BPA can be found in almost all products of modern civilization and it is widespread as a contaminant in the environment. BPA is an essential component of polycarbonate plastics and epoxy resins. Molecules that are not completely polymerized during the production process can leach from these plastics under normal conditions of use or are liberated from polymers exposed to heating or brushing or to specific $\mathrm{pH}$ ranges. BPA can thus be easily absorbed through the food chain (Vandenberg et al. 2012), as clearly shown by its presence in the human body. Levels of BPA ranging from 0.3 to $40 \mathrm{nM}$ have been detected in tissues and fluids during pregnancy (maternal and fetal serum, follicular and amniotic fluid, placenta; Ikezuki et al. 2002, He et al. 2009, Cao et al. 2012). BPA mimics the action of estrogens and alters multiple endocrine-related pathways, thus resulting in negative effects on female reproduction both in animals and in humans. Regrettably, the underlying mechanism(s) by which BPA disturbs the multiple events of female reproduction has not been fully characterized (LeBlanc 2012). In vitro and in vivo studies, as well as epidemiological evidence, associated BPA exposure to recurrent miscarriage, male infertility, altered gonadotropin hormone secretion, early pubertal onset, and altered ovarian granulosa steroidogenesis (Talsness et al. 2009, Kwintkiewicz et al. 2010, Liu et al. 2015). What is more, BPA not only impairs the reproductive efficiency but also could be connected with the onset of reproductive pathologies, such as endometriosis, polycystic ovary, and endometrial hyperplasia (Newbold et al. 2007, Cobellis et al. 2009, Signorile et al. 2012, Upson et al. 2014). 
In a recent report, we showed that BPA acts on the human trophoblast by increasing the secretion of human chorionic gonadotropin subunit beta ( $\beta$-hCG) and the macrophage migration inhibitory factor (MIF) (Mannelli et al. 2014). These effects on the human placenta were abolished/ diminished by previous absorption of BPA by endometrial stromal cells. Indeed, endometrial cells are able to retain $\mathrm{BPA}$, thus reducing exposure of the placenta to this chemical (Mannelli et al. 2014). Given the endocrine effects of BPA, its accumulation in endometrial cells could have important consequences for reproductive success.

\section{The role of the decidua in human pregnancy}

The decidua plays a key role in regulating trophoblast invasion and placental formation, by regulating the secretion of locally produced factors, under the control of corpus luteum steroids (Singh et al. 2011). During the cycle, the endometrium undergoes dramatic cyclic changes regarding cell proliferation, secretory activity, regression, and regeneration. Hormonal stimuli lead the endometrium to form the decidua in the luteal phase at the end of each cycle. The proper development of the maternal decidua and the molecular cross-talk between the decidua and the fetal trophoblast are of paramount importance for blastocyst invasion into the endometrium, implantation, and successful pregnancy. The importance of the endometrial stroma in this cross-talk resides in the fact that steroid hormones target endometrial stromal cells, which in turn facilitate the interaction between the blastocyst and the uterine epithelium (Ghosh \& Sengupta 1998, Caballero-Campo et al. 2002, Bourdiec et al. 2013).

\section{The role of steroid hormones on endometrial maturation/decidualization}

The main modulator of the proliferative phase of the cycle is $17 \beta$-estradiol $\left(E_{2}\right)$, which causes endometrial growth and thickening. Progesterone $\left(\mathrm{P}_{4}\right)$ induces cell differentiation in the estrogen-primed endometrium during the secretory phase; it also prepares epithelial cells for blastocyst attachment and provokes decidualization in stromal cells (Hombach-Klonisch et al. 2005). The concerted action of estrogens and $\mathrm{P}_{4}$ is of paramount importance for endometrial receptivity to the embryo (Sharkey \& Smith 2003).

\section{The role of the hCG hormone on endometrial receptivity}

The $\beta$-hCG subunit is secreted by the trophoblast, starting from the earliest stages of gestation (Cole 2009, Handschuh et al. 2009, Tsampalas et al. 2010), and acts on the endometrium through the hCG/luteinizing hormone receptor (LH-R), playing a key role in embryo implantation (Kasahara et al. 2012).

\section{The role of a pro-inflammatory environment on the deciduas}

Among the many cytokines present in the endometrial milieu, MIF is a key component of the pro-inflammatory environment characterizing the beginning of pregnancy. This cytokine is indeed highly expressed at the site of implantation by both the trophoblast and decidua (Arcuri et al. 1999, 2001).

\section{The potential deleterious effect of BPA on human decidua}

The interplay between the endocrine and paracrine factors involved in uterine receptivity and embryo implantation could easily be disrupted by hormonemimicking compounds such as BPA, with a drastic negative impact on pregnancy.

In order to shed light on the potential of BPA in affecting endometrial maturation, receptivity, and functions, an in vitro model of endometrial decidualized stromal cells was exposed to BPA at selected non-toxic concentrations. Cells were then assayed for expression of hormone receptors, e.g., estrogen receptors ( $E R \alpha$ and $E R \beta$ ), progesterone receptors (PRs), hCG/LH-R, biomarkers of decidualization, and cytokine secretion, e.g., insulin-like growth factor-binding protein (IGFBP1), decidual prolactin (dPRL), and MIF.

\section{Materials and methods}

\section{Tissues}

Biopsies, about $0.5 \mathrm{~cm}^{3}$ each, of healthy human endometrium (total $n=6$ hysterectomy specimens from different donors, all from the early proliferative phase of the cycle; see Table 1) were obtained from the Prefectural Hospital of Olsztyn (Poland) $(n=3$ specimens) and the Hospital of Campostaggia (Siena, Italy) $(n=3$ specimens), after written informed consent of the patients and with approval of the Local Ethics Committee (490/12/Bioet, for the Hospital of Olsztyn and VITRORIP 2013, for the Hospital of Campostaggia), in accordance with the Helsinki Declaration guidelines. Dating of the endometrial tissue was performed according to the date of the last menstrual period and to standard histological dating performed in the hospital (Noyes et al. 1950). The characteristics of the patients and tissues are described in Table 1.

\section{Culture and decidualization of endometrial stromal cells}

Endometrial stromal cells were isolated as described by Hombach-Klonisch et al. (2005) with some modifications (Mannelli et al. 2014). The purity of the stromal cells from each specimen was confirmed by immunocytochemistry using vimentin staining and flow cytometry as 
Table 1 Characteristics of patients and tissues.

\begin{tabular}{|c|c|c|c|c|}
\hline Patient & Cycle phase & Age (years) & Kind of intervention & Experimental protocol \\
\hline 1 & Proliferative endometrium & 38 & Hysterectomy for leiomyoma & AlamarBlue assay, ELISA, and qRT-PCR \\
\hline 2 & Proliferative endometrium & 44 & Hysterectomy for leiomyoma & AlamarBlue assay, ELISA, and qRT-PCR \\
\hline 3 & Proliferative endometrium & 45 & Hysterectomy for leiomyoma & AlamarBlue assay, ELISA, and western blot \\
\hline 4 & Proliferative endometrium & 33 & $\begin{array}{l}\text { Hysteroscopy for evaluation of the } \\
\text { morphology of the uterine cavity }\end{array}$ & $\begin{array}{l}\text { AlamarBlue assay, ELISA, western blot, } \\
\text { and qRT-PCR }\end{array}$ \\
\hline 5 & Proliferative endometrium & 35 & $\begin{array}{l}\text { Hysteroscopy for evaluation of the } \\
\text { morphology of the uterine cavity }\end{array}$ & $\begin{array}{l}\text { AlamarBlue assay, ELISA, western blot, } \\
\text { and qRT-PCR }\end{array}$ \\
\hline 6 & Proliferative endometrium & 34 & $\begin{array}{l}\text { Hysteroscopy for evaluation of the } \\
\text { morphology of the uterine cavity }\end{array}$ & ELISA, western blot, and qRT-PCR \\
\hline
\end{tabular}

previously described (Mannelli et al. 2014). Isolated stromal cells were cultured and propagated in complete medium: phenol red-free DMEM-F12 (Lonza Bio Whittaker, Verviers, Belgium), supplemented with $10 \%$ fetal bovine serum (Sigma-Aldrich), and $1 \%$ antibiotic/antimycotic (Sigma-Aldrich) in six-well plates (Becton Dickinson Falcon, Franklin Lakes, NJ, USA) and incubated in a humidified atmosphere of $5 \% \mathrm{CO}_{2}$ in air at $37^{\circ} \mathrm{C}$. At passage $2,1 \mathrm{ml}$ of cell suspension $\left(1 \times 10^{6}\right.$ cells/ $\mathrm{ml}$ ) was seeded in $75 \mathrm{~cm}^{2}$ flasks (Becton Dickinson Falcon) and cultured in complete medium until $70-80 \%$ confluence. Cells were then decidualized and used for BPA treatments as described below.

In order to achieve decidualization, cells were cultured in complete medium without hormones for the first 3 days; then, in order to mimic the proliferative phase of the cycle, the medium was supplemented with $\mathrm{E}_{2}\left(10^{-8} \mathrm{M}\right)$ (Sigma-Aldrich) for a further 3 days. Finally, the cells were exposed to $\mathrm{E}_{2}+\mathrm{P}_{4}\left(10^{-8}\right.$ and $10^{-6} \mathrm{M}$, respectively; Sigma-Aldrich) for up to 12 days to mimic the secretory phase (Schutte \& Taylor 2012). Decidualization was assessed by measuring the release of IGFBP1 and the mRNA transcription of dPRL.

\section{Experimental procedures}

Experiment 1: effect of BPA on decidualized human stromal cell viability and proliferation

In order to assess BPA cytotoxicity, decidualized human stromal cells ( $n=5$ specimens) were seeded into 96-well plates (TPP, Trasadingen, Switzerland) in complete medium. After $80-90 \%$ confluence was reached, cells were maintained in starvation medium (devoid of hormonal stimuli; phenol red-free DMEM-F12 supplemented with $0.1 \%$ BSA and $1 \%$ antibiotic/antimycotic) for a further $24 \mathrm{~h}$. The medium was then removed and substituted with fresh starvation medium containing BPA (Sigma-Aldrich) at concentrations ranging from $1 \mathrm{pM}$ to $1 \mu \mathrm{M}$ (namely, $1 \mathrm{pM}, 10 \mathrm{pM}, 100 \mathrm{pM}, 1 \mathrm{nM}, 10 \mathrm{nM}$, $100 \mathrm{nM}$, and $1 \mu \mathrm{M}$ from a stock solution in $\mathrm{EtOH})$. Control cultures were carried out with medium alone or a medium-containing vehicle $(0.1 \% \mathrm{EtOH}$ final concentration) in order to assess if the vehicle influences cell viability. All of the treatments and control were run in triplicates. At $24 \mathrm{~h}$, cells were assessed for cell viability using the AlamarBlue assay (Invitrogen).

After first screening on the cytotoxic effect of BPA, the effect of this chemical on the cell proliferative activity was assessed by BrdU assay. Decidualized human stromal cells ( $n=3$ specimens) were seeded into 96-well plates (TPP) in complete medium. After 80-90\% confluence was reached, cells were maintained in starvation medium (devoid of hormonal stimuli; phenol red-free DMEM-F12 supplemented with $0.1 \%$ BSA and $1 \%$ antibiotic/antimycotic) for a further $24 \mathrm{~h}$. The medium was then removed and substituted with fresh starvation medium containing BPA (Sigma-Aldrich) at concentrations ranging from $1 \mathrm{pM}$ to $100 \mu \mathrm{M}$ (namely, $1 \mathrm{pM}, 10 \mathrm{pM}, 100 \mathrm{pM}, 1 \mathrm{nM}, 10 \mathrm{nM}, 100 \mathrm{nM}$, and $1 \mu \mathrm{M}$ from a stock solution in EtOH). Control cultures were carried out with a medium-containing vehicle $(0.1 \%$ $\mathrm{EtOH}$ final concentration). All of the treatments and control were run in five replicates. Twenty-two hours before the end of exposure to BPA (namely, 24 and $48 \mathrm{~h}$ ), $\mathrm{BrdU}$ reagent was added and cell proliferation was assessed using the BrdU assay (QIA58, Calbiochem Millipore, Darmstadt, Germany), following the manufacturer's instructions.

\section{Experiment 2: Effect of BPA on biomarkers of endometrial maturation/decidualization}

Decidualized human stromal cells (at least $n=4$ from different donors) were seeded in $75 \mathrm{~cm}^{2}$ flasks or in 24-well plates for protein or mRNA transcription analysis respectively. Cells were cultured in complete medium until an $80-90 \%$ confluence was reached, then cells were maintained in a starvation medium for $24 \mathrm{~h}$. The medium was removed and substituted with a fresh starvation medium containing BPA at the non-toxic concentrations of $1 \mathrm{pM}, 1 \mathrm{nM}$, or $1 \mu \mathrm{M}$ or a vehicle alone $(0.1 \% \mathrm{EtOH})$. At $24 \mathrm{~h}$ of incubation, the conditioned medium was collected, centrifuged at $13000 \mathrm{~g}$ at $4{ }^{\circ} \mathrm{C}$ for $10 \mathrm{~min}$ and stored at $-80^{\circ} \mathrm{C}$ until protein determination (see below) by ELISA.

Cells were processed for mRNA transcription as follows: cells were harvested in TriReagent solution 
(Sigma-Aldrich), and total RNA and DNA were extracted. RNA was purified using the RNA Pep Plus Kit (A\&A Biotechnology, Gdansk, Poland). Transcribed cDNA samples were stored at $-80{ }^{\circ} \mathrm{C}$ until assayed by quantitative real-time PCR (qRT-PCR) for the selected markers (see below).

For protein analysis, the cells were harvested in ice-cold RIPA lysis buffer (Tris-base $40 \mathrm{mM}, \mathrm{NaCl} 150 \mathrm{mM}$, EDTA $500 \mathrm{nM}$, Triton X-100 1\%, sodium deoxycholate 0.5\%, and SDS $0.1 \%$ ) containing a protease inhibitor cocktail (Sigma-Aldrich) and then sonicated on ice. Protein lysates were centrifuged at $12000 \mathrm{~g}$ for $15 \mathrm{~min}$ at $4{ }^{\circ} \mathrm{C}$ and stored at $-80^{\circ} \mathrm{C}$ until assayed for the selected markers (see below) by western blotting.

Decidualized human stromal cells $(n=4$ specimens for IGFBP1 and dPRL analysis, $n=5$ for ER $\alpha$, ER $\beta$, and PRs) were seeded in $75 \mathrm{~cm}^{2}$ flasks or in 24-well plates for protein or mRNA transcription analysis respectively. Cells were cultured as described above and samples of cell medium, protein lysated, and mRNA were collected as described above. The mRNA expression of dPRL, ER $\alpha$ and ER $\beta$, and PRs was assessed by qRT-PCR. The release of the IGFBP1 protein in the culture media was assessed by ELISA.

Experiment 3: effect of BPA on endometrial receptivity on hormonal actions (receptors' expression)

Decidualized human stromal cells ( $n=5$ specimens) were seeded in $75 \mathrm{~cm}^{2}$ flasks or in 24-well plates for protein or mRNA transcription analysis respectively. Cells were cultured as described above, and samples of cell medium, protein lysated, and mRNA were collected as described above. The transcriptional level of $E R \alpha$, ER $\beta$, PRs, and hCG/LH-R was assessed by qRT-PCR, while their protein expression was assessed by western blotting.

Experiment 4: effect of BPA on a biomarker of the endometrial pro-inflammatory environment

Decidualized human stromal cells ( $n=5$ specimens) were seeded in $75 \mathrm{~cm}^{2}$ flasks or in 24-well plates for protein or mRNA transcription analysis respectively. Cells were cultured as described above, and samples of cell medium, protein lysated, and mRNA were collected as described above. The transcriptional level of MIF was assessed by qRT-PCR, while its protein expression was assessed by western blotting.

\section{AlamarBlue assay}

The AlamarBlue assay (Invitrogen) indicates cell viability by using the reducing power of living cells to convert resazurin into a fluorescent molecule, resorufin. In order to assess the cytotoxicity of BPA, the conditioned medium from BPA-treated or control cultures was removed and AlamarBlue solution (diluted 1:10) was added to each well.
After 4 h incubation in a humidified atmosphere of $5 \% \mathrm{CO}_{2}$ in air at $37^{\circ} \mathrm{C}$, absorbance was measured with a Synergy $\mathrm{H} 1$ hybrid reader (Biotek, Winooski, VT, USA) at $570 \mathrm{~nm}$.

\section{BrdU assay}

The BrdU cell proliferation assay is an immunoassay for the quantification of de novo synthesis of DNA by actively proliferating cells. In order to assess the proliferation of cells, the exposure medium from BPA-treated or control cultures was removed and BrdU solution (diluted 1:2000) was added to each well. After $22 \mathrm{~h}$ incubation in a humidified atmosphere of $5 \% \mathrm{CO}_{2}$ in air at $37{ }^{\circ} \mathrm{C}$, the content of the wells was removed and cells were fixed with fixative solution and incubated at room temperature for $30 \mathrm{~min}$. Anti-BrdU antibody (diluted 1:100 in antibody dilution buffer) was then added and incubated for $1 \mathrm{~h}$ at room temperature. After three washes with $1 \times$ washing buffer, peroxidase goat anti-mouse IgG HRP conjugate was added to the wells and incubated for $30 \mathrm{~min}$ at room temperature. After three washes with washing buffer and one wash with distilled water, the substrate solution was added to each well and incubated, repaired from light, for $15 \mathrm{~min}$ at room temperature, and the reaction was interrupted by adding the stop solution. Absorbance was measured with a Synergy H1 Hybrid Reader (Biotek) at 450-540 nm.

\section{ELISA}

\section{IGF-binding protein 1}

The amount of IGFBP1 was quantified in the conditioned medium from BPA-treated cultures by a specific ELISA (R\&D Systems, Minneapolis, MN, USA) following the manufacturer's instructions. All of the samples were assayed in duplicate and a standard curve ranging from 12.5 to $2000 \mathrm{pg} / \mathrm{ml}$ was run in each experiment, using human recombinant IGFBP1 (R\&D Systems). The data were normalized against the total DNA content, measured by NanoDrop (Thermo Scientific, Hudson, $\mathrm{NH}$, USA). The IGFBP1 concentration was expressed as $\mathrm{pg} / \mu \mathrm{g}$ of total DNA.

\section{Migration inhibitory factor}

The concentration of MIF in the conditioned medium of BPA-treated cultures was assayed by a colorimetric sandwich ELISA, as previously described by letta et al. (2007). All samples were assayed in duplicate and a standard curve ranging from 25 to $2500 \mathrm{pg} / \mathrm{ml}$ was run in each experiment, using bacterially expressed recombinant human MIF (R\&D Systems). The sensitivity limit of the assay was $18 \mathrm{pg} / \mathrm{ml}$. Intra- and inter-assay coefficients of variation were $3.86(0.95)$ and $9.14 \quad(0.47) \%$ respectively. The data were normalized against the total protein content from cell lysates, measured by the 
Bradford protein assay (Bio-Rad). The MIF concentration was expressed as $\mathrm{pg} / \mu \mathrm{g}$ of total protein.

\section{Western blot}

Aliquots of $50 \mu \mathrm{g}$ proteins from cell lysates were run on $10 \%$ polyacrylamide gel to separate $\mathrm{ER} \alpha, \mathrm{ER} \beta, \mathrm{PR}$, $\mathrm{hCG} / \mathrm{LH}-\mathrm{R}$, and $\beta$-actin, in the presence of SDS and $\beta$-mercaptoethanol. After electrophoresis, the intact gels were then equilibrated in transfer buffer $(20 \mathrm{mM}$ Tris, $190 \mathrm{mM}$ glycine, and 20\% (v/v) methanol, $\mathrm{pH}$ 8.3) for $5 \mathrm{~min}$ at room temperature. Proteins were transferred to a PVDF membrane (Millipore Corporation, Billerica, MA, USA) for $1 \mathrm{~h}$. The membrane was incubated overnight with $5 \%(\mathrm{wt} / \mathrm{v})$ low-fat milk in a PBS buffer supplemented with $0.1 \%$ Tween 20 as a blocking solution, then the membrane was exposed to one of the following antibodies: mouse anti-human $\mathrm{ER} \alpha$ (ab9269, dilution 1:100; Abcam, Cambridge, UK), mouse anti-human ER $\beta$ (ab288, Abcam, dilution 1:100), mouse anti-human PR (recognizing both isoforms, PRA and PRB) (ab2764, Abcam, dilution 1:100), rabbit anti-human hCG/LH-R (H-50 sc25828, Santa Cruz Biotechnology, dilution 1:100). All of the membranes were then exposed to mouse anti-human $\beta$-actin (A3854, Sigma-Aldrich, dilution 1:3000) antibody. The PVDF membranes were washed three times with PBST $(0.1 \%$ Tween 20 in PBS $10 \mathrm{mM})$ and exposed to a goat anti-mouse or goat anti-rabbit antibody, depending on the primary antibody used, and labeled with peroxidase (Bio-Rad). Then, the membranes were washed three times with PBST and visualized with a chemiluminescence kit (Luminata forte, Millipore Corporation), according to the manufacturer's instructions. The data were normalized against $\beta$-actin by using mouse anti-human $\beta$-actin antibody.

\section{Quantitative RT-PCR}

RNA concentration and quality of the extracted total RNA were determined spectrophotometrically (NanoDrop, Thermo Scientific) and by agarose gel electrophoresis. The ratio of absorbance, calculated by the ND-1000 v3.8.0 Software at 260 and $280 \mathrm{~nm}$ (OD, $A_{260 / 280)}$ ), was $\sim 2$. Then, $1 \mu \mathrm{g}$ RNA was reverse transcribed into cDNA using a ThermoScript RT-PCR System (Qiagen), according to the manufacturer's instructions. The cDNA was stored at $-20^{\circ} \mathrm{C}$ until real-time PCR was performed. The primers for SYBR Green were designed and validated from the literature using gene features of the National Center for Biotechnology (NCBI) website, Primer3 and BEACON (Premier Biosoft, Palo Alto, CA, USA; Table 2). The PRB isoform primer was designed from a fragment in the coding region unique to PRB (Gargiulo-Monachelli et al. 2014), whereas, because the PRA region is included in the PRB sequence, the primer for PRA-PRB was selected from a common fragment, described in Schaefer et al. (2010). The primer for GADPH was chosen from the report by Cao et al. (2005). Primer sequences, expected PCR product lengths, and GenBank accession numbers are reported in Table 2. The specificity of the chosen primers was checked using the nucleotide BLAST tool of the NCBI website. Fluorescence qRT-PCR was performed using the Applied Biosystems 7900 HT FastRealTime System (Applied Biosystems) with SYBR Green PCR Master Mix (Power SYBR Green PCR Master Mix, Applied Biosystems) following the manufacturer's instructions. The 384-well plates were used. Total reaction volume was $10 \mu \mathrm{l}$ containing $3 \mu \mathrm{l}$ reversetranscribed cDNA $(1 \mathrm{ng} / \mu \mathrm{l}), 1 \mu \mathrm{l}$ forward and reverse primers each $(250 \mathrm{nM})$, and $5 \mu \mathrm{l}$ SYBR Green PCR Master Mix. Amplification was preceded by an initial denaturation step $\left(10 \mathrm{~min}\right.$ at $\left.95^{\circ} \mathrm{C}\right)$. The PCR program for the gene was performed as follows: 40 cycles of denaturation $\left(15 \mathrm{~s}\right.$ at $\left.95^{\circ} \mathrm{C}\right)$, annealing $\left(30 \mathrm{~s}\right.$ at $\left.56^{\circ} \mathrm{C}\right)$, and elongation $\left(60 \mathrm{~s}\right.$ at $\left.72{ }^{\circ} \mathrm{C}\right)$. After each PCR, melting curves were obtained by stepwise increases in temperature from 50 to $95{ }^{\circ} \mathrm{C}$ to ensure single product amplification.

In the case of ER $\beta$ and hCG/LH-R, TaqMan probes for ER $\beta$ and hCG-LH-R were selected and used as specified by the manufacturer (Applied Biosystems). Briefly, genomic DNA was eliminated by the addition of Master Mix 1 solution for $5 \mathrm{~min}$, then the Master Mix 2 solution

Table 2 List of the primers used for the qRT-PCR.

\begin{tabular}{|c|c|c|c|c|}
\hline Gene name & Sequence $\left(5^{\prime}-3^{\prime}\right)$ & Accession number & Melting temperature $\left({ }^{\circ} \mathrm{C}\right)$ & Product size (bp) \\
\hline$E R \alpha$ & $\begin{array}{l}\text { F: TGCCAAGGAGACTCGCTACTG } \\
\text { R: CAGCCCTCACAGGACCAGAC }\end{array}$ & NM_001122742.1 & $\begin{array}{l}66.7 \\
67.4\end{array}$ & 81 \\
\hline$P R A-P R B$ & $\begin{array}{l}\text { F: TTTAAGAGGGCAATGGAAGG } \\
\text { R: CGGATTTTTATCAACGATGCAG }\end{array}$ & NM_001271161.2 & $\begin{array}{l}62.8 \\
64.1\end{array}$ & 74 \\
\hline$P R B$ & $\begin{array}{l}\text { F: ACACCTTGCCTGAAGTTTCG } \\
\text { R: GACTGCTGGTCCTGCGTCTT }\end{array}$ & NM_001271161.2 & $\begin{array}{l}64.2 \\
66.9\end{array}$ & 109 \\
\hline MIF & $\begin{array}{l}\text { F: AGCCCGGACAGGGTCTACAT } \\
\text { R: GCGAAGGTGGAGTTGTTCCA }\end{array}$ & NM_002415.1 & $\begin{array}{l}66.9 \\
67.4\end{array}$ & 74 \\
\hline$d P R L$ & $\begin{array}{l}\text { F: CATCAACAGCTGCAACACTT } \\
\text { R: CGTTTGGTTTGCTCCTCAAT }\end{array}$ & NM_001163558.2 & $\begin{array}{l}61.6 \\
63.9\end{array}$ & 213 \\
\hline$G A D P H$ & $\begin{array}{l}\text { F: CAGGGCTGCTTTTAACTCTGG } \\
\text { R: TGGGTGGAATCATATTGGAACA }\end{array}$ & NM_001256799.1 & $\begin{array}{l}64.8 \\
65.9\end{array}$ & 102 \\
\hline
\end{tabular}




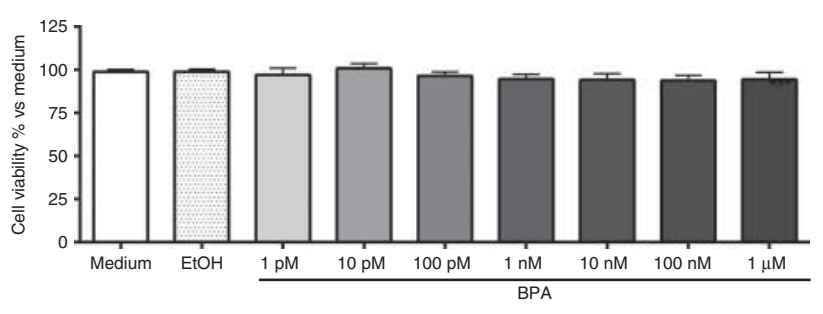

Figure 1 Effect of BPA on decidualized human endometrial stromal cell viability. The cells were treated with BPA $(1 \mathrm{pM}-1 \mu \mathrm{M})$ for $24 \mathrm{~h}$, with vehicle $(0.1 \% \mathrm{EtOH})$, or with medium only, and then assessed by AlamarBlue assay. Values are expressed as percentage mean \pm s.E.M. vs medium; data was obtained from at least five separate experiments, each using tissue from a different donor.

was added, and the RNA was reverse-transcribed into cDNA at $50^{\circ} \mathrm{C}$ for 20 min (Applied Biosystems). An activation step of $5 \mathrm{~min}$ at annealing for $5 \mathrm{~min}$ at $95^{\circ} \mathrm{C}$ was followed by denaturation at the same temperature for $15 \mathrm{~s}$. The annealing/extension phase required a temperature of $60{ }^{\circ} \mathrm{C}$ for $30 \mathrm{~s}$. A total of 45 cycles was performed.

Data were elaborated by the Real-Time PCR Software SDS 2.4 (Bio-Rad). The specificity of PCR products was confirmed by electrophoresis on $2 \%$ agarose gel. To control sampling errors and normalize the data, PCR for the housekeeping gene GADPH was performed on each sample. The data were analyzed using the method described by Zhao \& Fernald (2005).

\section{Statistical analysis}

Data were analyzed on GraphPad Prism Version 5.0 (GraphPad Software, San Diego, CA, USA). The test for normal distribution was done in each experiment. Whenever the assumptions of normal distribution were not met, nonparametric analyses were done. All data are shown as percentage mean \pm s.E.M. All data were statistically analyzed by nonparametric one-way ANOVA Kruskal-Wallis followed by Dunn's test. Differences were considered significant if $P<0.05$.

\section{Results}

\section{Experiment 1: effect of BPA on decidualized human stromal cell viability and proliferation}

The vehicle had no effect on cell viability compared to cultures with medium only (Fig. 1). Concerning the exposure to BPA, the chemical did not significantly alter cell viability at any of the concentrations tested (Fig. 1). Furthermore, cell proliferation was monitored for 24 and $48 \mathrm{~h}$, and no significant changes were observed at the doses of BPA selected, except for the concentration of $100 \mathrm{nM}$, that proved to have a proliferative effect after $48 \mathrm{~h}$ (Fig. 2).

After this first screening on the effect of a wide range of BPA concentrations, for the following experiments three non-toxic concentrations of BPA, namely $1 \mathrm{pM}$, $1 \mathrm{nM}$, and $1 \mu \mathrm{M}$, were selected and the control group was exposed to the vehicle alone $(0.1 \% \mathrm{EtOH})$.

\section{Experiment 2: effect of BPA on biomarkers of endometrial maturation/decidualization}

Treatment with $1 \mu \mathrm{M}$ BPA significantly decreased the mRNA transcription of $d P R L(P<0.01$; Fig. 3). No significant effects were detected in the secretion of IGFBP1 upon exposure to BPA (Fig. 3). The basal IGFBP1 secretion was $23.1 \pm 4.4 \mathrm{pg} / \mu \mathrm{g}$ total DNA in control cultures, whereas it reached $37.9 \pm 11.84 \mathrm{pg} / \mu \mathrm{g}$ total DNA in BPA treatments.

\section{Experiment 3: effect of BPA on endometrial receptivity on hormonal actions (receptors' expression)}

An increase in the mRNA transcription of $E R \alpha$ was observed in all of the BPA concentrations tested, although $1 \mu \mathrm{M}$ and $1 \mathrm{nM}$ BPA were the most effective $(P<0.01$ for $1 \mu \mathrm{M}$ and $1 \mathrm{nM}$ BPA vs control (Fig. 4); $P<0.05$ for $1 \mathrm{pM}$ BPA vs control) (Fig. 4). After treatment with $1 \mathrm{nM} \mathrm{BPA,}$ ER $\beta$ protein expression and mRNA transcription were up-regulated (Fig. 4, E and F; $P<0.05$ ).

The PR protein expression was up-regulated by treatment with $1 \mu \mathrm{M}$ BPA $(P<0.05$; Fig. $5 \mathrm{~A}$ and $\mathrm{B})$. PRA and PRB mRNA transcription was up-regulated upon treatment with $1 \mu \mathrm{M} \mathrm{BPA}(P<0.01$; Fig. $5 \mathrm{C})$. A not significant trend was observed at the transcription level for the isoform B of PR (Fig. 5D). Protein expression of

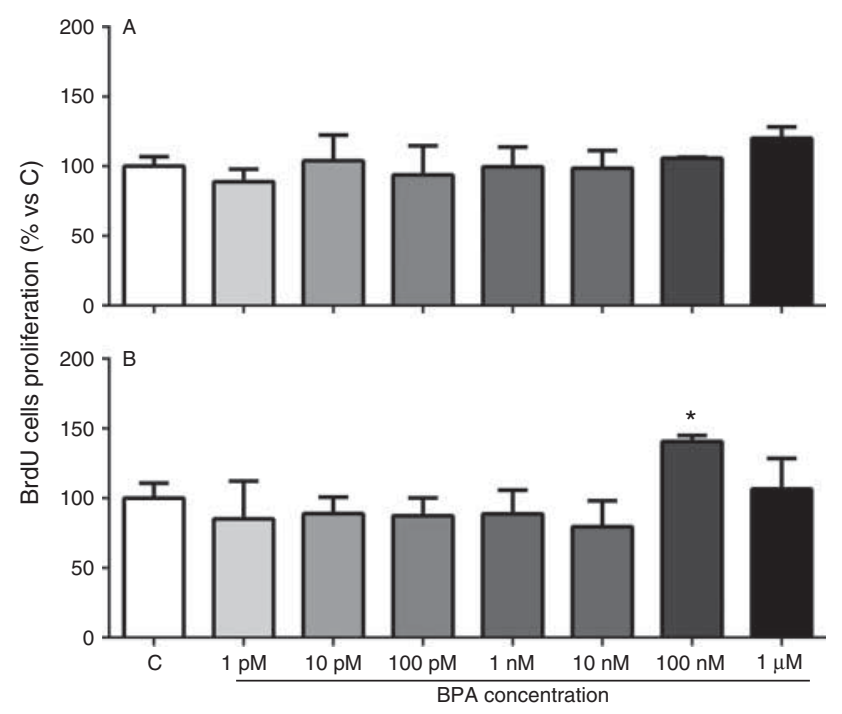

Figure 2 Effect of BPA on decidualized human endometrial stromal cell proliferation. The cells were treated with $\mathrm{BPA}(1 \mathrm{pM}-1 \mu \mathrm{M})$ or with vehicle (control (C) $=\mathrm{EtOH} 0.1 \%$ ) for $24(\mathrm{~A})$ or $48 \mathrm{~h}$ (B), and then assessed by BrdU assay. Values are expressed as percentage mean \pm s.E.M. vs control; data was obtained from at least three separate experiments, each using tissue from a different donor $\left({ }^{*} P<0.05\right.$ vs control). 

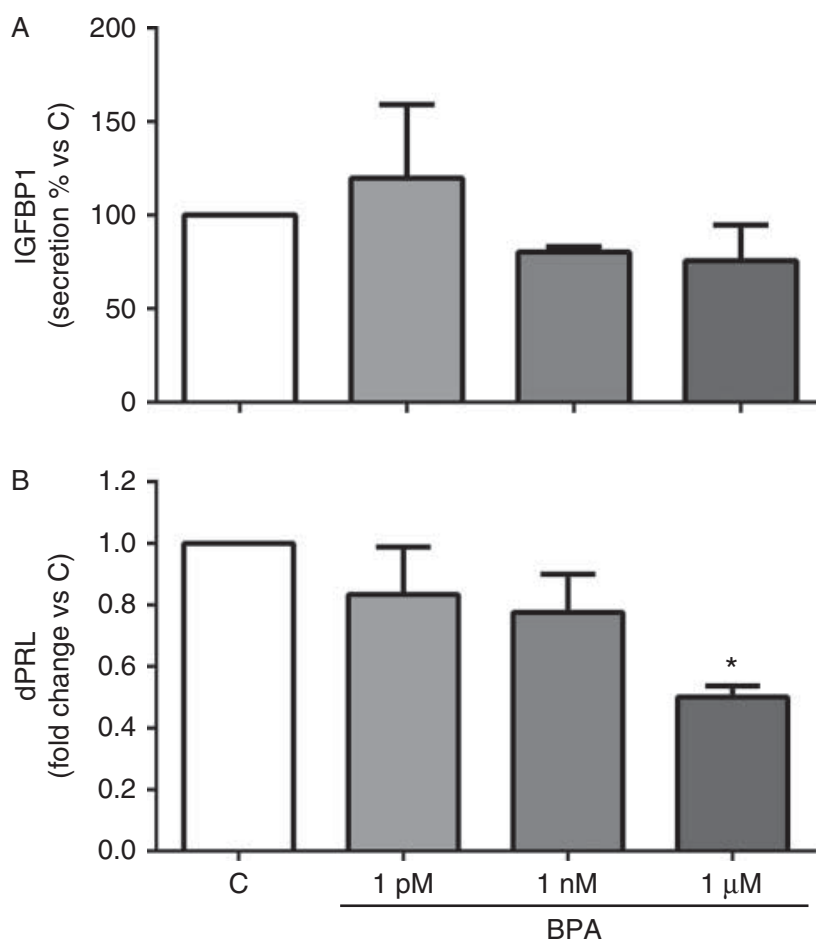

Figure 3 Effect of BPA on biomarkers of endometrial decidualization. IGFBP1 secretion (A) and DPRL mRNA transcription (B) in in vitro decidualized human endometrial stromal cells treated with BPA at concentrations of $1 \mathrm{pM}, 1 \mathrm{nM}, 1 \mu \mathrm{M}$, or exposed to a vehicle $(0.1 \%$ $\mathrm{EtOH}$ ) (C) for $24 \mathrm{~h}$. (A) Secretion of IGFBP1 in culture medium, detected by ELISA. Values were normalized against the amount of total DNA and reported as percentage mean \pm S.E.M. vs control (C) of four separate experiments, each using tissue from different donors. (B) Transcription of mRNA of dPRL detected by qRT-PCR. Data were normalized against the level of GADPH mRNA transcription and expressed as $n$-fold change mean \pm S.E.M. relative to control of four separate experiments $\left({ }^{*} P<0.05\right.$ vs control).

hCG/LH-R was decreased by BPA at the level of $1 \mathrm{pM}$ compared to the control group ( $P<0.05$; Fig. $6 \mathrm{~A}$ and $\mathrm{B})$. No significant changes were observed at the transcriptional level for this receptor (Fig. 6C).

\section{Experiment 4: effect of BPA on a biomarker of the endometrial pro-inflammatory environment}

The basal secretion of MIF in the control medium was $0.21 \pm 0.014 \mathrm{pg} / \mu \mathrm{g}$ of total protein, whereas it reached an average value of $0.59 \pm 0.53 \mathrm{pg} / \mu \mathrm{g}$ of total protein in the treatments with BPA.

The secretion of MIF was enhanced by all treatments; the lowest concentration (1 pM) was the most effective and higher vs the other two BPA treatments $(1 \mathrm{nM}$ and $1 \mu \mathrm{M}) \quad(P<0.001$ for all treatments vs control and $P<0.001$ for $1 \mathrm{pM}$ BPA vs $1 \mu \mathrm{M}$ and $1 \mathrm{nM}$ BPA) (Fig. 7A). On the other hand, the mRNA transcription of MIF was not significantly different in the different concentrations of BPA (Fig. 7B).

\section{Discussion}

The goal of this work was to define potential adverse effects of BPA on the functions of human decidua by challenging the cells to BPA for a short-term exposure. For this purpose, an in vitro model of decidual stromal cells was used, as these cells contribute greatly to the formation of the decidua, thus playing a major role in embryonic implantation and pregnancy. At first, decidual stromal cells were exposed to a wide range of BPA concentrations in order to examine the potential toxicity of this chemical. Because none of the concentrations tested diminished cell viability by $50 \%$, it was not possible to detect the $\mathrm{LC}_{50}$, which represents the concentration that causes a half-maximal decrease in cell viability. Similarly, findings reported by Schaefer et al. (2010) did not show any significant decrease in cell viability in an endometrial adenocarcinoma cell line, Ishikawa cells, after exposure to BPA up to $1 \mu \mathrm{M}$. Concerning the effect of BPA on the proliferative activity of endometrial cells, none of the concentrations used (from $1 \mathrm{pM}$ to $1 \mu \mathrm{M}$ ) decreased the de novo synthesis of DNA, whereas a significant proliferative effect could be noticed in cells treated with $10 \mathrm{nM}$ BPA after $48 \mathrm{~h}$ of exposure. This result could be due to the estrogen-like activity of BPA and to a dose-dependent effect (Baker \& Chandsawangbhuwana 2012).
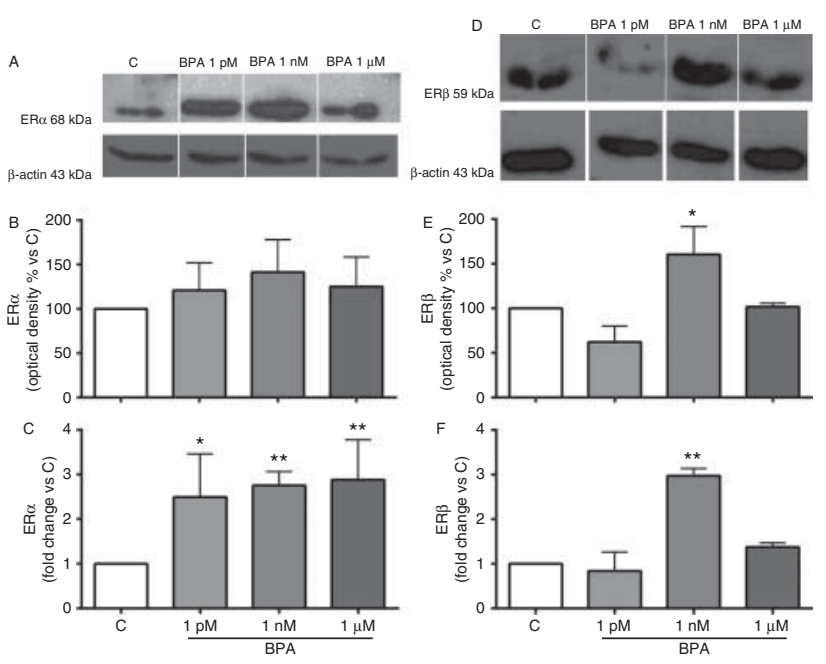

Figure 4 Expression of $E R \alpha(A, B$ and $C)$ and $E R \beta(D, E$ and $F)$ in in vitro decidualized human endometrial stromal cells treated with BPA (1 pM, $1 \mathrm{nM}$, and $1 \mu \mathrm{M})$ or exposed to vehicle only $(0.1 \% \mathrm{EtOH})(\mathrm{C})$ for $24 \mathrm{~h}$. (A and D) Protein expression of ER $\alpha$ and ER $\beta$ performed by western blotting. The images show cropped bands from the same electrophoresis. ( $\mathrm{B}$ and $\mathrm{E}$ ) The values from densitometry were normalized against the expression of $\beta$-actin and expressed as percentage mean \pm S.E.M. vs control (C) in four separate experiments, each with tissue from different donors. ( $C$ and $F$ ) Transcription of mRNA of ER $\alpha$ and ER $\beta$. All real-time PCR data were normalized to the level of GADPH mRNA and represented as $n$-fold change mean \pm s.E.M. relative to control in four separate experiments $\left({ }^{*} P<0.05\right.$ vs control and ${ }^{* *} P<0.01$ vs control). 

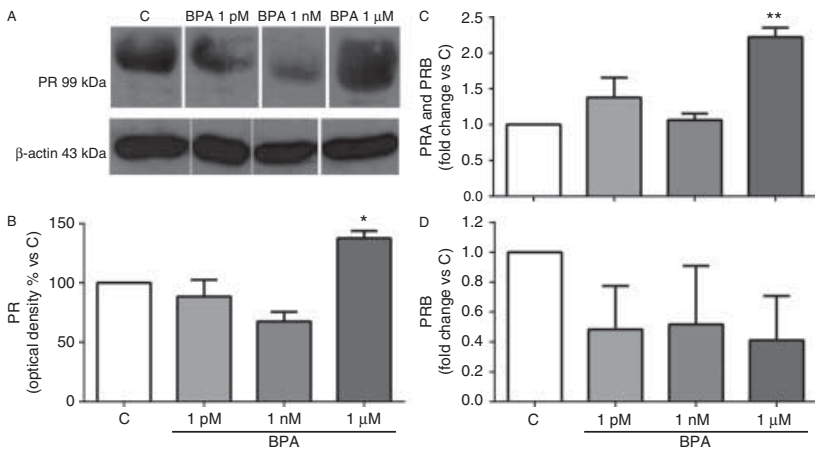

Figure 5 Expression of PRs in in vitro decidualized human endometrial stromal cells treated with BPA ( $1 \mathrm{pM}, 1 \mathrm{nM}$, and $1 \mu \mathrm{M})$ or exposed to vehicle $(0.1 \% \mathrm{EtOH})(\mathrm{C})$ for $24 \mathrm{~h}$. (A) Protein expression of PR performed by western blotting. The image shows cropped bands from the same electrophoresis. (B) The values from densitometry were normalized against the expression of $\beta$-actin and expressed as percentage mean \pm S.E.M. vs control $(C)$ of four separate experiments using tissue from different donors $\left({ }^{*} P<0.05\right.$ vs control). (C) Transcription of mRNA of PRA and PRB. (D) Transcription of mRNA of PRB. All real-time PCR data were normalized to the level of GADPH mRNA and reported as $n$-fold change mean \pm s.E.M. relative to control of four separate experiments $\left({ }^{* *} P<0.01\right.$ vs control).

\section{Effect of BPA on secretion of biomarkers of endometrial maturation/decidualization}

Based on the findings from experiment 1 , we selected three non-toxic concentrations ( $1 \mathrm{pM}, 1 \mathrm{nM}$, and $1 \mu \mathrm{M})$ to examine the effects of BPA on key biomarkers of decidualization. The concentrations selected, particularly $1 \mathrm{nM}$ and $1 \mathrm{pM}$, were also 'environmentally relevant' because they can be easily found in the environment and in human tissues (Benijts et al. 2004). As far as pregnancy is concerned, levels detected in the maternal and fetal fluids are in the $\mathrm{nM}$ range or less (Ikezuki et al. 2002, Schönfelder et al. 2002). In particular, $1 \mathrm{pM}$ BPA was selected to represent a very low concentration, even lower than the BPA concentration detected in the human body; $1 \mathrm{nM}$ BPA is a concentration that stays within the physiological range of concentrations that has been detected in the human population, and finally $1 \mu \mathrm{M}$ BPA is the highest used in the functional study (experiments 2-4) and represents chronic, high exposure/accumulation of BPA in human tissues. None of the concentrations tested were toxic on the decidualized stromal cells as shown by the cytotoxicity assay. To the best of our knowledge, such low concentrations of BPA had never previously been tested on human decidual cells.

BPA has been reported to alter endometrial decidualization in vitro and in murine models (Varayoud et al. 2008, Aghajanova \& Giudice 2011). By assaying specific markers, we demonstrated that the highest concentration of BPA $(1 \mu \mathrm{M})$ significantly decreased the mRNA transcription of PRL, while, although showing a decrease at higher concentrations, the effect on IGFBP1 was not statistically significant. These data are once again at odds with those of Aghajanova \& Giudice (2011), who found altered levels of IGFBP1 but not of PRL. As discussed above, the incongruity between our results and those of Aghajanova \& Giudice (2011) can be explained by the different BPA concentrations and exposure times used (Bredhult et al. 2007, Naciff et al. 2010).

The choice of short-term exposure $(24 \mathrm{~h})$ in the present study was guided by the report by Naciff et al. (2010) who demonstrated that within this exposure time BPA is already able to alter the gene expression profile of Ishikawa cells. Taken together, the pieces of evidence that show an effect of 0.001 for all treatments vs control BPA on endometrial cell decidualization do raise concern, because altered transformation of the
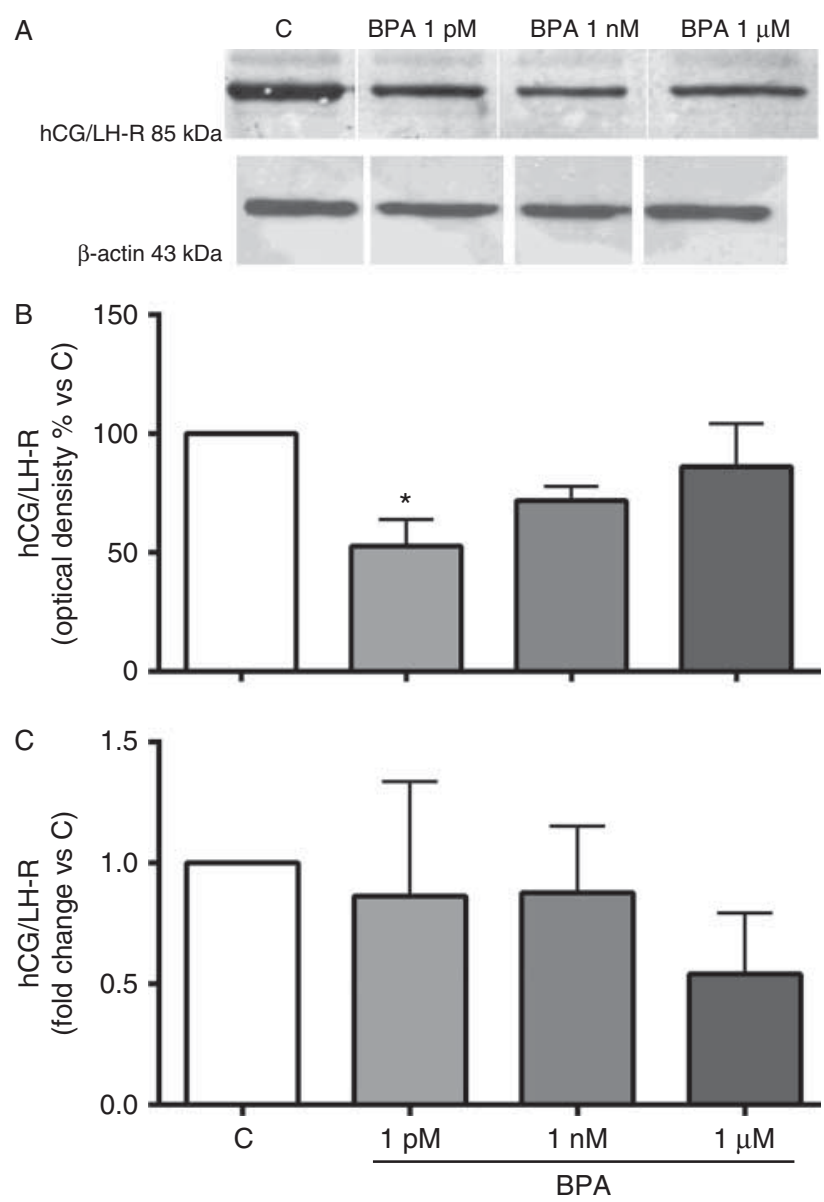

Figure 6 Expression of hCG/LH-R in in vitro decidualized human endometrial stromal cells treated with BPA $(1 \mathrm{pM}, 1 \mathrm{nM}$, and $1 \mu \mathrm{M})$ or exposed to vehicle $(0.1 \% \mathrm{EtOH})(\mathrm{C})$ for $24 \mathrm{~h}$. (A) Protein expression of hCG/LH-R analyzed by western blotting. The image shows cropped bands from the same electrophoresis. (B) The values from densitometry were normalized against the expression of $\beta$-actin and reported as percentage mean \pm S.E.M. relative to control $(C)$ in four separate experiments using tissue from different donors. (C) Transcription of mRNA of hCG/LH-R. All real-time PCR data were normalized to the level of GADPH mRNA and represented as $n$-fold change mean \pm s.E.M. vs control of four separate experiments $\left({ }^{*} P<0.05\right.$ vs control). 

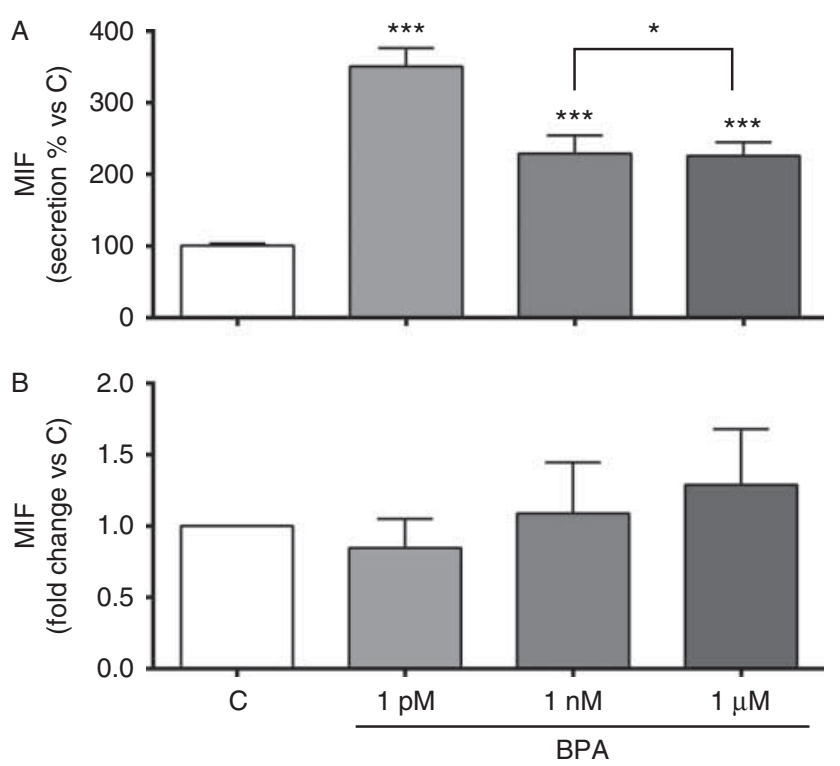

Figure 7 Macrophage migration inhibitory factor secretion (A) and its mRNA transcription (B) in in vitro decidualized human endometrial stromal cells treated with BPA ( $1 \mathrm{pM}, 1 \mathrm{nM}$, and $1 \mu \mathrm{M})$ or exposed to vehicle $(0.1 \% \mathrm{EtOH})(\mathrm{C})$ for $24 \mathrm{~h}$. (A) Secretion of MIF in culture media, detected by ELISA. Values were normalized against the amount of total protein and reported as percentage mean \pm S.E.M. relative to control (C) of five separate experiments each using tissue from different donors (*** $P<$ and $* P<0.001$ for $1 \mathrm{pM}$ BPA vs $1 \mu \mathrm{M}$ and $1 \mathrm{nM} \mathrm{BPA})$. (B) Transcription of mRNA of MIF detected by qRT-PCR. All data were normalized to the level of GADPH mRNA and reported as $n$-fold change mean \pm S.E.M. relative to control of four separate experiments.

endometrium might contribute to reduced success of implantation (Singh et al. 2011). Furthermore, many reports show that low levels of PRL are frequently found in cases of recurrent pregnancy loss or spontaneous early miscarriage (Salker et al. 2010, Garzia et al. 2013).

\section{Effect of BPA on endometrial receptivity on hormonal actions (receptors' expression)}

As for the effects of BPA on ERs, evidence of BPA estrogenic action is reported with MCF7 cells (a breast cancer cell line) and in in vivo experiments in rats (Miyakoshi et al. 2009, Berger et al. 2010). Accordingly, our results showed that $E R \alpha$, the isoform involved in BPAmediated effects (Bouskine et al. 2009, Jeng \& Watson 2011), was enhanced by all concentrations tested. While $\mathrm{ER} \alpha$ was significantly up-regulated by BPA only at the mRNA level, ER $\beta$ protein was up-regulated by an environmentally relevant concentration of BPA $(1 \mathrm{nM})$.

Concerning the PRs, we detected a band at $\sim 99 \mathrm{kDa}$, which is in line with the molecular weight of isoform $A$ of the PR (predicted molecular weight: $94 \mathrm{kDa}$ ). Even though the antibody used should detect both isoforms of $\mathrm{PR}$, no upper bands were detected (PRB has a predicted molecular weight of $120 \mathrm{kDa}$ ). As demonstrated by Yin et al. (2010), PRB is much less expressed in uterine cells than PRA, and this could be the reason we were unable to detect the protein level of $P R$ isoform $B$. Our findings demonstrated that $1 \mu \mathrm{M}$ BPA up-regulated both the protein and transcription levels of PRs (the primer was designed to detect both isoforms), and this effect seemed to be led by an up-regulation of PRA, because the mRNA levels paralleled the protein levels of PRA. On the other hand, the mRNA levels of the PRB isoform remained below the controls. Interestingly, in many cell types PRA acts as an inhibitor of the gene transcription activated by PRB (Tung et al. 1993). Nevertheless, the consequences of the BPA-driven increase of PRA expression requires further investigation.

Altogether, these data show that BPA is able to modulate steroid receptors, and this could easily lead to altered proliferation and transformation of stromal cells in the endometrium (Schaefer et al. 2010, Singh et al. 2011). During the window of receptivity, steroid hormones facilitate the interaction between the blastocyst and the uterine epithelium via the endometrial stroma (Ghosh \& Sengupta 1998, Caballero-Campo et al. 2002, Bourdiec et al. 2013). Therefore, an altered pattern of expression of their receptors in the decidua could well have a negative impact on female fertility, especially on the success of implantation.

The expression of the hCG/LH-R varies during the cycle, reaching a peak during the secretory phase (Reshef et al. 1990, Kasahara et al. 2012). The cycledependent expression of the hCG/LH-R suggests that it is modulated by steroid hormones. Whereas estrogens contribute to the stimulation of this receptor in the rat ovary (Ikeda et al. 2008), we demonstrated that BPA negatively modulates the expression of the hCG/LH-R at $1 \mathrm{pM}$. Furthermore, our recent report (Mannelli et al. 2014) showed that BPA alters $\beta$-hCG secretion by the human placenta. Altogether, these two findings show that BPA could disrupt the signaling of a key hormone of the feto-maternal cross-talk.

\section{Effect of BPA on a biomarker of the endometrial pro-inflammatory environment}

Concerning the marker of the pro-inflammatory environment tested, MIF secretion by endometrial cells was significantly enhanced by BPA at all concentrations tested, the lowest ( $1 \mathrm{pM})$ concentration being the most effective. In previous studies on human placenta, letta et al. (2010) demonstrated that low doses of $E_{2}$ stimulated MIF secretion, whereas higher doses downregulated it. Because BPA has weak estrogenic activity (Kuiper et al. 1998, Rubin 2011), its stimulatory effect in MIF secretion observed here could be similar to that exerted by low doses of $E_{2}$. The macrophage MIF is a major component of the inflammatory uterine milieu at the site of implantation. Its decrease in maternal serum in early pregnancy has been associated with first trimester miscarriages (Yamada et al. 2003). However, while the 
secretion of MIF is beneficial to the establishment of pregnancy, an exaggerated response could result in an unfavorable pregnancy outcome. Higher MIF levels have in fact been detected in severe pregnancy disorders such as pre-eclampsia and pre-term labor (Todros et al. 2005, Cardaropoli et al. 2012, Rolfo et al. 2013). In line with the present data in decidual cells, we recently demonstrated that BPA stimulates MIF secretion by human trophoblast (Mannelli et al. 2014). Consequently, increased levels of MIF at the site of implantation may occur in a mother exposed to BPA and therefore might be harmful to pregnancy and fetal health.

Altogether, these data show that very low BPA concentrations, which can be easily detected in the population, are able to influence the maternal-trophoblast environment. Indeed, BPA had an adverse affect on the expression of decidual markers and hormone receptors in endometrial decidualized stromal cells. The effects observed could have a negative effect on pregnancy establishment and development.

\section{Declaration of interest}

The authors declare that there is no conflict of interest that could be perceived as prejudicing the impartiality of the research reported.

\section{Funding}

The study has been supported by the 'Preludium' Grant of National Science Centre no. 2013/09/N/NZ5/03062 and from Fondazione Monte dei Paschi of Siena (Siena, Italy). A Z Szóstek was supported by Domestic Grants for Young Scientists of the Foundation of Polish Science (FNP, Program Start, Poland).

\section{References}

Aghajanova L \& Giudice LC 2011 Effect of bisphenol A on human endometrial stromal fibroblasts in vitro. Reproductive Biomedicine Online 22 249-256. (doi:10.1016/j.rbmo.2010.12.007)

Arcuri F, Sestini S \& Cintorino M 1999 Expression of $11 \beta$-hydroxysteroid dehydrogenase in early pregnancy: implications in human trophoblastendometrial interactions. Seminars in Reproductive Endocrinology 17 53-61. (doi:10.1055/s-2007-1016212)

Arcuri F, Ricci C, letta F, Cintorino M, Tripodi SA, Cetin I, Garzia E, Schatz F, Klemi P, Santopietro R et al. 2001 Macrophage migration inhibitory factor in the human endometrium: expression and localization during the menstrual cycle and early pregnancy. Biology of Reproduction 64 1200-1205. (doi:10.1095/biolreprod64.4.1200)

Baker ME \& Chandsawangbhuwana C 2012 3D models of MBP, a biologically active metabolite of bisphenol $\mathrm{A}$, in human estrogen receptor $\alpha$ and estrogen receptor $\beta$. PLOS ONE 7 e46078. (doi:10.1371/journal.pone.0046078)

Benijts T, Lambert W \& De Leenheer A 2004 Analysis of multiple endocrine disruptors in environmental waters via wide-spectrum solid-phase extraction and dual-polarity ionization LC-ion trap-MS/MS. Analytical Chemistry 76 704-711. (doi:10.1021/ac035062x)

Berger RG, Foster WG \& deCatanzaro D 2010 Bisphenol-A exposure during the period of blastocyst implantation alters uterine morphology and perturbs measures of estrogen and progesterone receptor expression in mice. Reproductive Toxicology 30393-400. (doi:10.1016/j.reprotox.2010.06.006)
Bourdiec A, Bédard D, Rao CV \& Akoum A 2013 Human chorionic gonadotropin regulates endothelial cell responsiveness to interleukin 1 and amplifies the cytokine-mediated effect on cell proliferation, migration and the release of angiogenic factors. American Journal of Reproductive Immunology 70 127-138. (doi:10.1111/aji.12080)

Bouskine A, Nebout M, Brücker-Davis F, Benahmed M \& Fenichel P 2009 Low doses of bisphenol A promote human seminoma cell proliferation by activating PKA and PKG via a membrane G-protein-coupled estrogen receptor. Environmental Health Perspectives 117 1053-1058. (doi:10.1289/ehp.0800367)

Bredhult C, Bäcklin B-M \& Olovsson M 2007 Effects of some endocrine disruptors on the proliferation and viability of human endometrial endothelial cells in vitro. Reproductive Toxicology 23 550-559. (doi:10.1016/j.reprotox.2007.03.006)

Caballero-Campo P, Domínguez F, Coloma J, Meseguer M, Remohí J, Pellicer A \& Simón C 2002 Hormonal and embryonic regulation of chemokines IL-8, MCP-1 and RANTES in the human endometrium during the window of implantation. Molecular Human Reproduction 8 375-384. (doi:10.1093/molehr/8.4.375)

Cao W-G, Morin M, Metz C, Maheux R \& Akoum A 2005 Stimulation of macrophage migration inhibitory factor expression in endometrial stromal cells by interleukin 1, $\beta$ involving the nuclear transcription factor NFKB. Biology of Reproduction 73 565-570. (doi:10.1095/ biolreprod.104.038331)

Cao X-L, Zhang J, Goodyer CG, Hayward S, Cooke GM \& Curran IH 2012 Bisphenol $\mathrm{A}$ in human placental and fetal liver tissues collected from Greater Montreal area (Quebec) during 1998-2008. Chemosphere 89 505-511. (doi:10.1016/j.chemosphere.2012.05.003)

Cardaropoli S, Paulesu L, Romagnoli R, letta F, Marzioni D, Castellucci M, Rolfo A, Vasario E, Piccoli E \& Todros T 2012 Macrophage migration inhibitory factor in fetoplacental tissues from preeclamptic pregnancies with or without fetal growth restriction. Clinical \& Developmental Immunology 2012 639342. (doi:10.1155/2012/639342)

Cobellis L, Colacurci N, Trabucco E, Carpentiero C \& Grumetto L 2009 Measurement of bisphenol A and bisphenol B levels in human blood sera from healthy and endometriotic women. Biomedical Chromatography 23 1186-1190. (doi:10.1002/bmc.1241)

Cole LA 2009 New discoveries on the biology and detection of human chorionic gonadotropin. Reproductive Biology and Endocrinology 78. (doi:10.1186/1477-7827-7-8)

Gargiulo-Monachelli GM, Campos-Melo D, Droppelmann CA, Keller BA, Leystra-Lantz C, De Nicola AF, Gonzalez Deniselle MC, Volkening K \& Strong MJ 2014 Expression and cellular localization of the classical progesterone receptor in healthy and amyotrophic lateral sclerosis affected spinal cord. European Journal of Neurology 21 273-e11. (doi:10.1111/ene.12291)

Garzia E, Clauser R, Persani L, Borgato S, Bulfamante G, Avagliano L, Quadrelli F \& Marconi AM 2013 Prolactin and proinflammatory cytokine expression at the fetomaternal interface in first trimester miscarriage. Fertility and Sterility 100 108-115 (e1-2). (doi:10.1016/j.fertnstert.2013.02.053)

Ghosh D \& Sengupta J 1998 Recent developments in endocrinology and paracrinology of blastocyst implantation in the primate. Human Reproduction Update 4 153-168. (doi:10.1093/humupd/4.2.153)

Handschuh K, Guibourdenche J, Cocquebert M, Tsatsaris V, Vidaud M, Evain-Brion D \& Fournier T 2009 Expression and regulation by PPAR $\gamma$ of hCG $\alpha$ - and $\beta$-subunits: comparison between villous and invasive extravillous trophoblastic cells. Placenta 30 1016-1022. (doi:10.1016/j. placenta.2009.09.006)

He Y, Miao M, Herrinton LJ, Wu C, Yuan W, Zhou Z \& Li D-K 2009 Bisphenol A levels in blood and urine in a Chinese population and the personal factors affecting the levels. Environmental Research 109 629-633. (doi:10.1016/j.envres.2009.04.003)

Hombach-Klonisch S, Kehlen A, Fowler PA, Huppertz B, Jugert JF, Bischoff G, Schlüter E, Buchmann J \& Klonisch T 2005 Regulation of functional steroid receptors and ligand-induced responses in telomeraseimmortalized human endometrial epithelial cells. Journal of Molecular Endocrinology 34 517-534. (doi:10.1677/jme.1.01550)

letta F, Wu Y, Romagnoli R, Soleymanlou N, Orsini B, Zamudio S, Paulesu L \& Caniggia I 2007 Oxygen regulation of macrophage migration inhibitory factor in human placenta. American Journal of Physiology. Endocrinology and Metabolism 292 E272-E280. (doi:10.1152/ajpendo. 00086.2006) 
letta F, Bechi N, Romagnoli R, Bhattacharjee J, Realacci M, Di Vito M, Ferretti C \& Paulesu L 2010 17 $\beta$-Estradiol modulates the macrophage migration inhibitory factor secretory pathway by regulating ABCA1 expression in human first-trimester placenta. American Journal of Physiology. Endocrinology and Metabolism 298 E411-E418. (doi:10.1152/ajpendo.00522.2009)

Ikeda S, Nakamura K, Kogure K, Omori Y, Yamashita S, Kubota K, Mizutani T, Miyamoto K \& Minegishi T 2008 Effect of estrogen on the expression of luteinizing hormone-human chorionic gonadotropin receptor messenger ribonucleic acid in cultured rat granulosa cells. Endocrinology 149 1524-1533. (doi:10.1210/en.2007-1163)

Ikezuki Y, Tsutsumi O, Takai Y, Kamei Y \& Taketani Y 2002 Determination of bisphenol A concentrations in human biological fluids reveals significant early prenatal exposure. Human Reproduction $\mathbf{1 7}$ 2839-2841. (doi:10.1093/humrep/17.11.2839)

Jeng Y-J \& Watson CS 2011 Combinations of physiologic estrogens with xenoestrogens alter ERK phosphorylation profiles in rat pituitary cells. Environmental Health Perspectives 119 104-112. (doi:10.1289/ehp. 1002512)

Kasahara Y, Kitahara Y, Nakamura K \& Minegishi T 2012 Downregulation of $\mathrm{LH}$ receptor mRNA in the rat uterus. Molecular Medicine Reports $\mathbf{5}$ 1146-1150. (doi:10.3892/mmr.2012.795)

Kuiper GG, Lemmen JG, Carlsson B, Corton JC, Safe SH, van der Saag PT, van der Burg B \& Gustafsson JA 1998 Interaction of estrogenic chemicals and phytoestrogens with estrogen receptor $\beta$. Endocrinology 139 4252-4263. (doi:10.1210/endo.139.10.6216)

Kwintkiewicz J, Nishi Y, Yanase T \& Giudice LC 2010 Peroxisome proliferatoractivated receptor- $\gamma$ mediates bisphenol A inhibition of FSH-stimulated IGF1, aromatase, and estradiol in human granulosa cells. Environmental Health Perspectives 118 400-406. (doi:10.1289/ehp.0901161)

LeBlanc SJ 2012 Interactions of metabolism, inflammation, and reproductive tract health in the postpartum period in dairy cattle. Reproduction in Domestic Animals 47 (Suppl 5) 18-30. (doi:10.1111/j.1439-0531.2012. 02109.x)

Liu X, Miao M, Zhou Z, Gao E, Chen J, Wang J, Sun F, Yuan W \& Li D-K 2015 Exposure to bisphenol-A and reproductive hormones among male adults. Environmental Toxicology and Pharmacology 39 934-941. (doi:10.1016/j.etap.2015.03.007)

Mannelli C, letta F, Carotenuto C, Romagnoli R, Szostek AZ, Wasniewski T, Skarzynski DJ \& Paulesu L 2014 Bisphenol A alters $\beta$-hCG and MIF release by human placenta: an in vitro study to understand the role of endometrial cells. Mediators of Inflammation 2014 Article ID 635364. (doi:10.1155/2014/635364)

Miyakoshi T, Miyajima K, Takekoshi S \& Osamura RY 2009 The influence of endocrine disrupting chemicals on the proliferation of $E R \alpha$ knockdownhuman breast cancer cell line MCF-7; new attempts by RNAi technology. Acta Histochemica et Cytochemica 42 23-28. (doi:10.1267/ahc.08036)

Naciff JM, Khambatta ZS, Reichling TD, Carr GJ, Tiesman JP, Singleton DW, Khan SA \& Daston GP 2010 The genomic response of Ishikawa cells to bisphenol A exposure is dose- and time-dependent. Toxicology 270 137-149. (doi:10.1016/j.tox.2010.02.008)

Newbold RR, Jefferson WN \& Padilla-Banks E 2007 Long-term adverse effects of neonatal exposure to bisphenol A on the murine female reproductive tract. Reproductive Toxicology 24 253-258. (doi:10.1016/ j.reprotox.2007.07.006)

Noyes R, Hertig A \& Rock J 1950 Dating the endometrial biopsy: obstetrical \& gynecological survey. Gynecology 5 561-564.

Reshef E, Lei ZM, Rao CV, Pridham DD, Chegini N \& Luborsky JL 1990 The presence of gonadotropin receptors in nonpregnant human uterus, human placenta, fetal membranes, and decidua. Journal of Clinical Endocrinology and Metabolism 70 421-430. (doi:10.1210/jcem-70-2-421)

Rolfo A, Giuffrida D, Nuzzo AM, Pierobon D, Cardaropoli S, Piccoli E, Giovarelli M \& Todros T 2013 Pro-inflammatory profile of preeclamptic placental mesenchymal stromal cells: new insights into the etiopathogenesis of preeclampsia. PLOS ONE 8 e59403. (doi:10.1371/journal. pone.0059403)

Rubin BS 2011 Bisphenol A: an endocrine disruptor with widespread exposure and multiple effects. Journal of Steroid Biochemistry and Molecular Biology 127 27-34. (doi:10.1016/j.jsbmb.2011.05.002)

Salker M, Teklenburg G, Molokhia M, Lavery S, Trew G, Aojanepong T, Mardon HJ, Lokugamage AU, Rai R, Landles C et al. 2010 Natural selection of human embryos: impaired decidualization of endometrium disables embryo-maternal interactions and causes recurrent pregnancy loss. PLoS ONE 5 e10287. (doi:10.1371/journal.pone.0010287)

Schaefer WR, Fischer L, Deppert WR, Hanjalic-Beck A, Seebacher L, Weimer M \& Zahradnik HP 2010 In vitro-Ishikawa cell test for assessing tissue-specific chemical effects on human endometrium. Reproductive Toxicology 30 89-93. (doi:10.1016/j.reprotox.2010.02.002)

Schönfelder G, Wittfoht W, Hopp H, Talsness CE, Paul M \& Chahoud I 2002 Parent bisphenol A accumulation in the human maternal-fetalplacental unit. Environmental Health Perspectives 110 A703-A707.

Schutte SC \& Taylor RN 2012 A tissue-engineered human endometrial stroma that responds to cues for secretory differentiation, decidualization, and menstruation. Fertility and Sterility 97 997-1003. (doi:10.1016/ j.fertnstert.2012.01.098)

Sharkey AM \& Smith SK 2003 The endometrium as a cause of implantation failure. Best Practice \& Research. Clinical Obstetrics \& Gynaecology 17 289-307. (doi:10.1016/S1521-6934(02)00130-X)

Signorile PG, Spugnini EP, Citro G, Viceconte R, Vincenzi B, Baldi F \& Baldi A 2012 Endocrine disruptors in utero cause ovarian damages linked to endometriosis. Frontiers in Bioscience 4 1724-1730. (doi:10.2741/E493)

Singh M, Chaudhry P \& Asselin E 2011 Bridging endometrial receptivity and implantation: network of hormones, cytokines, and growth factors. Journal of Endocrinology 210 5-14. (doi:10.1530/JOE-10-0461)

Talsness CE, Andrade AJM, Kuriyama SN, Taylor JA \& vom Saal FS 2009 Components of plastic: experimental studies in animals and relevance for human health. Philosophical Transactions of the Royal Society of London. Series B, Biological Sciences 364 2079-2096. (doi:10.1098/rstb.2008.0281)

Todros T, Bontempo S, Piccoli E, letta F, Romagnoli R, Biolcati M, Castellucci M \& Paulesu L 2005 Increased levels of macrophage migration inhibitory factor (MIF) in preeclampsia. European Journal of Obstetrics, Gynecology, and Reproductive Biology 123 162-166. (doi:10.1016/j.ejogrb.2005.03.014)

Tsampalas M, Gridelet V, Berndt S, Foidart J-M, Geenen V \& Perrier d'Hauterive S 2010 Human chorionic gonadotropin: a hormone with immunological and angiogenic properties. Journal of Reproductive Immunology 85 93-98. (doi:10.1016/j.jri.2009.11.008)

Tung L, Mohamed MK, Hoeffler JP, Takimoto GS \& Horwitz KB 1993 Antagonist-occupied human progesterone B-receptors activate transcription without binding to progesterone response elements and are dominantly inhibited by A-receptors. Molecular Endocrinology 7 1256-1265. (doi:10. 1210/mend.7.10.8123133)

Upson K, Sathyanarayana S, De Roos AJ, Koch HM, Scholes D \& Holt VL 2014 A population-based case-control study of urinary bisphenol A concentrations and risk of endometriosis. Human Reproduction 29 2457-2464. (doi:10.1093/humrep/deu227)

Vandenberg LN, Chahoud I, Heindel JJ, Padmanabhan V, Paumgartten FJ \& Schoenfelder G 2012 Urinary, circulating, and tissue biomonitoring studies indicate widespread exposure to bisphenol A. Ciência \& Saúde Coletiva 17 407-434.

Varayoud J, Ramos JG, Bosquiazzo VL, Muñoz-de-Toro M \& Luque EH 2008 Developmental exposure to bisphenol A impairs the uterine response to ovarian steroids in the adult. Endocrinology 149 5848-5860. (doi:10.1210/en.2008-0651)

Yamada H, Kato EH, Morikawa M, Shimada S, Saito H, Watari M, Minakami H \& Nishihira J 2003 Decreased serum levels of macrophage migration inhibition factor in miscarriages with normal chromosome karyotype. Human Reproduction 18 616-620. (doi:10.1093/humrep/deg147)

Yin P, Lin Z, Reierstad S, Wu J, Ishikawa H, Marsh EE, Innes J, Cheng Y, Pearson K, Coon JS et al. 2010 Transcription factor KLF11 integrates progesterone receptor signaling and proliferation in uterine leiomyoma cells. Cancer Research 70 1722-1730. (doi:10.1158/0008-5472.CAN-09-2612)

Zhao S \& Fernald RD 2005 Comprehensive algorithm for quantitative realtime polymerase chain reaction. Journal of Computational Biology 12 1047-1064. (doi:10.1089/cmb.2005.12.1047)

Received 17 November 2014

First decision 9 January 2015

Revised manuscript received 22 May 2015

Accepted 28 May 2015 